\title{
A Critical Review and Significance of Ayurvedic preparation Kwatha - Herbal decoction
}

\author{
Review Article
}

\section{Narendra Someshwar Bhatt ${ }^{*}, 3$, Manasi Deshpande ${ }^{2}$}

1. Hon. Research Director and Adjunct Professor, 2. Professor and Head, Department of Dravyaguna Vigynan, Bharati Vidyapeeth Deemed to be University, College of Ayurved, Pune, India

3. CRIA Consultants Pvt. Ltd, 15, J. B. Marg, Parel, Mumbai 400012 India

\begin{abstract}
The standardization of Ayurvedic classical dosage forms has been an area of academic, research, industrial and regulatory interests. It is crucial to understand the basic principles and rationality of these dosage forms for their therapeutic relevance while adapting to newer technologies for its right pharmaceutical and clinical use. Kwatha Kalpana -frequently referred to as decoctions - aqueous extraction of a group of herbs, is one of the most commonly used classical dosage forms where the therapeutic attributes are extracted from the group of botanicals into water, with the use of heat. Though clinically effective, it is seldom used due to the cumbersome preparatory method, short shelf life and poor palatability. This elaborate review covers historical and basic concepts of the dosage form, its salient features, nuances of classical preparations, traditional and newly developed methods of preparations. This paper covers intricate classical information and specifics about Kwatha, the herbal decoction.
\end{abstract}

Key Words: Ayurvedic dosage form, Kwatha, Kashayam, Decoction, Standardization, Ayurvedic teas, Ayurvedic Pharmacy.

\section{Introduction}

Kwatha Kalpana - decoction or infusion is a well-known Ayurvedic dosage form based on the principle of boiling and obtaining water-soluble constituents from herbs. Kwatha, decoction is one of the panchvidha kashaya kalpana (1) i.e. group of five main categories of Ayurvedic pharmaceutics: the others being Swarasa - fresh juice, Kalka - paste, Hima - cold infusion and Phanta - hot infusion. As a dosage form, Kwatha, the herbal decoctions have a wide range of therapeutic uses in the treatment of various diseases. Kwatha is also used as an ingredient to prepare other dosage forms used orally such as for guti-vati - pills, avaleha - medicinal jams, ghrita - medicinal ghee or asava-arishta- medicinal wines and topically as for medicinal oils and several other forms.

\section{Need for the Review of Ayurvedic Dosage Forms \\ 'Bhaishajya Kalpana' - Ayurvedic pharmaceutics is a well-developed sub-discipline of Ayurveda covering more than 40 pharmaceutical dosage forms to provide a variety of therapeutic solutions. It describes all the details, including identification of raw materials and the meticulous methods of preparation.}

\section{* Corresponding Author:}

\section{Narendra Someshwar Bhatt}

Hon. Research Director and Adjunct Professor,

Bharati Vidyapeeth Deemed to be University,

College of Ayurved, Pune, India

Email Id: drnsbhatt@gmail.com
Kwatha - herbal decoction as an age-old dosage form has not only been sustained, but has also progressed into newer forms as marketable products. It is important to understand the basic principles and evolution of this traditional dosage form based on Ayurvedic classical literature and to review it in the context of modern pharmaceutical developments. A similar review on Asava-arishta, self-generated alcohol-based products was carried out by us.(2)

\section{Review of the classics}

Ayurvedic literature comprises of vedic, samhita and nighantoo - compendia texts.

\section{Vedic Period (1500-500 BCE)}

Vedic literature refers to Kashaya formulation. There are vedic references of decoctions namely Dashmoolkashaya and Parushakadikashaya to treat ailments and of combining dravya - substance to jalawater as formulations. Atharvaveda (3) describes 'Karambh' which is prepared with aushadhi dravyas medicinal substances and water. A reference of decoction made of Haritaki - Terminalia chebula Retz. is indicated for dental ailments.(4)

\section{Samhita Period (300-500 BCE)}

The samhitas, the Ayurvedic treatises describe the methods of preparation of 'Shrita' - decoction and their classifications as used to treat different diseases. Charaka Samhita mentions that decoction being prepared with heat is lighter to digest than the fresh juice and paste.(1) It also provides details of the preparation in which dravya - raw drug is boiled with 
drava - liquid media for a specific period. Ashtang Hridaya describes the method like kwatha for preparation of Shrita.(5)

Chakrapani, the commentator of Charak Samhita suggests the tastelessness of residual material as indicative of the right preparation.(6) Sushrut Samhita includes Kashaya kalpana, kwatha as one of the six types of basic forms, the sixth being Ksheera kalpana - milk based products.(7)

\section{Compendia}

Sharangdhar Samhita, (14th Century A.D.) a well-known compendium on formulations, uses the terms Shruta, Kashaya, and Niryuha for decoction. The text has a separate chapter with detailed description about the preparatory methods of different decoctions that relate to its use for different ailments. It has also described upakalpanas - allied variants, namely Pramathya where raw plant parts are added in the form of paste, Yavagu, a gruel prepared in a similar way with rice, Yush, gruels using different pulses, Shadangapaneeya, medicated water with six constituents, Ksheerapaka- milk boiled with plant parts, and other Aharakalpanas - dietetic preparations having medicinal values like Manda - watery portion of rice gruel, Peya- gruel made with cooked rice and Vilepi- thick rice gruel and others.(8)

Bhavaprakash (16 $6^{\text {th }}$ Century AD) a well-known compendium of classical products using natural ingredients provides variable ratios of plant parts to water for preparation of decoctions to be administered into three groups as large, medium and small.(9)

Kashyapa samhita, (6 $6^{\text {th }}$ Century BCE) a treatise mainly covering the health of women, children and reproductive system includes seven types of dosage forms as churna - powder, sheeta Kashaya - cold infusion, swarasa - expressed juice, abhishava fermented preparations, phanta - hot infusion, kalka paste and kwatha - decoction with details of methods of preparation.(10)

Harita Samhita describes seven types of Kashaya and also suggests lesser reduction of water for tarpana - nourishing purpose and stronger process, higher water reduction for apatarpana- cleansing (11). Todarananda, a later period author has described similarly seven types of decoctions along with their therapeutic attributes.(12)

\section{Definitions of terms}

The word Kashaya generally refers to kashaya rasa (astringent taste); ' $K a$ ': denotes kaya -shareera (body); 'Sha': denotes functions; ' $Y a$ ': denotes appropriate regulation. Kashaya means the one that helps regulate body functions or helps maintain equilibrium (13,14). Vaidyaka Shabdasindhu (15), classical text on Sanskrit medical terms implies that kashaya is kwatha - decoction. Vachaspatyam, an ancient Sanskrit dictionary has defined Kashaya (16) kashhinsayamdhatu + aaypratyayakashati kantham as one meant to remove doshas from kantha - throat, the upper part. Ayurvediya Shabdakosh, a lexicon of Ayurvedic terms explains it as a shrut-kwathitam or utkwathitam, boiled dosage form that krupsamrthaye dhatu enables metabolism.(17)

Kwatha is a type of medicinal preparation in which coarsely powdered raw ingredient/s of natural origin are boiled with the liquid medium, usually water, for a fixed time until reduced to the desired volume. Thereafter, the entire product is filtered through a clean cloth. The liquid obtained after filtration is called a decoction.(18)

\section{Salient features}

- Herbal decoction is an effective and forceful dosage form as the water-soluble attributes of the herbs are extracted during the heating process to form a new product.

- Decoction is a liquid dosage form with water that is absorbed better and faster in the intestinal tract.

- It is considered laghu - lighter or, easy to absorb or metabolize.

- It is commonly indicated in many disease conditions.

- It provides a base for several other dosage forms like Avaleha - linctus, Snehapaka- Medicated oil and Ghee, Sandhankalpana- Fermented preparations and others.

\section{Pharmaceutical process \\ Traditional Method of Preparation}

Classical texts provide different methods of preparing Kwatha.

\section{Charak Samhita}

The medicinal herbs must be carefully examined for quality, cut into small pieces and washed thoroughly with water. Cow's urine is advised, if needed, to be added to half of the quantity of water. Cow's urine is commonly credited to remove all impurities. The material is to be boiled till it gets fully extracted in the water when the material becomes tasteless - gataraseshu aushadheshu.(19) The mixture is to be stirred intermittently to avoid herbs getting burnt or stuck at the bottom of the vessel. According to Chakrapanidutta, the commentator of Charak Samhita after boiling, about $3 / 4^{\text {th }}$ of the water gets evaporated and when the extracted mass becomes tasteless, it is the confirmatory test of Kwatha. Generally, the decoction is prepared till the water gets reduced to $1 / 4^{\text {th }}$ unless otherwise specified.(7)

\section{Sushruta Samhita}

Sushruta along with the process (20) suggests the use of sun dried tvak - bark, patra - leaves, phala fruits and moola - root for preparation of decoction to use as a base for Snehapaka - preparing lipid-based formulations. Dalhan, its commentator, also provides the process for preparation of Rasakriya.(21)

\section{Ashtang Sangraha}

Vagbhatt recommends that the dried herbs be coarsely cut. The wide mouth vessel of copper, iron or earth is to be used to prepare a decoction. The water is to be added to the herbs and then boiled on low flame 
with continuous stirring and suggests use of lukewarm decoction after filtration.(22)

\section{Sharangadhara Samhita}

Sharangdhara suggests the use of an earthen vessel (23) and it should not be covered while boiling as it changes the attributes of decoction from laghu- easy to digest, to guru- hard to digest.(24)

\section{Kashyapa Samhita}

Kashyapa samhita states that one part of the drug is to be added with 4 or 8 times of water. The mixture is to be boiled on low flame till it reduces to $1 / 4^{\text {th }}$ of the quantity. Kashyap Samhita recommends the dose variation based on rugnabala - strength of the patient and vyadhibala - severity of the disease.(25) This process of preparation is endorsed by the recent scholars like Vaidya Yadavji Trikamji Acharya.(26)

\section{Preparation}

Collection of Crude Drugs

The raw material should be free of any extrinsic matter and other residual contaminants or pesticides.
The ingredients must be authenticated and should be collected and stored under hygienic conditions in required quantity.

\section{Vessels for Kwatha}

Traditionally used earthen pots (27) help control temperature, minimize environmental exchange and prevent loss of active or volatile substances. Metallic coated copper vessels and vessels with a coating of wet soil from outside were also used instead of an earthen pot.(28) Presently stainless-steel vessels are preferred due to availability, cost efficiency and easy maintenance.

\section{Proportion of water}

The proportion of water is recommended by different authors with respect to the therapeutic relevance of kwatha $(29,30,31)$ [Table 1]. It is indicated that the proportion of water varies with respect to hardness of the raw herbs used, e.g. mrudu soft, madhyam- medium, kathin - hard and atyant kathin- harder; especially while preparing Snehapaka oleaginous dosage form. $(32,33)$

Table 1: Variation in Proportion of Water and Reduction

Author Proportion of water and reduction

\begin{tabular}{|c|c|c|c|c|c|c|}
\hline & \\
\hline & $1: 16 \longrightarrow 1 / 8^{\text {th }}$ & $1: 16 \longrightarrow 1 / 4^{\text {th }}$ & $1: 16 \longrightarrow 1 / 16^{\text {th }}$ & $1: 8 \longrightarrow 1 / 4^{\text {th }}$ & $1: 4 \longrightarrow 1 / 4^{\text {th }}$ & $\begin{array}{l}1: 8 \text { or } 16 \longrightarrow \\
1 / 8^{\text {th }} \text { or } 1 / 16^{\text {th }}\end{array}$ \\
\hline Adhamalla & & + & & & & \\
\hline Arunadutta & & + & & & & \\
\hline Bhavamishra & + & + & & & & \\
\hline Chakrapanidutta & & + & & + & + & \\
\hline Dalhana & & & + & & & + \\
\hline Govindacharya & & & + & + & & + \\
\hline Hemadri & & + & & & & \\
\hline Kashyapa & & + & & & & \\
\hline Sharangadhara & + & & & & & \\
\hline Sushrut & & + & & + & + & \\
\hline
\end{tabular}

Sharangadhara, in the chapter of preparation of oleaginous dosage forms - Sneha Kalpana recommends reducing the quantity of water proportionate to the increased quantity of ingredients to acquire maximum extractives with the process of boiling [Table 2].

Table 2: Recommended Quantity of Water with Respect to Quantity of Ingredients (33)

\section{Quantity of Ingredients}

One karsh to one pal [12 grams to 48 grams]

More than 1 pal up to 1 kudava [48 grams to 192 grams]

More than 1 kudava to 1 khari [192 grams to $196 \mathrm{~kg}$ ] Volume of Water 16 times 8 times 4 times
Quantity after Reduction $1 / 4^{\text {th }}$

$1 / 4^{\text {th }}$

$1 / 4^{\text {th }}$

\section{Heat, Temperature}

Heat, temperature is an important factor because there are chances that temperature can decompose some of the thermo-labile active constituents. Classical texts have suggested mandagni - mild heat for preparation of decoction which is usually maintained between $85-90^{\circ} \mathrm{C}$.(34) During the process occasional stirring is required for proper homogenous treatment to the substances.(35)

\section{Particle size of raw materials}

The particle size of raw material is customarily Yavkutchurna- coarse powder or the size of barley grains.(36)

\section{Duration of heating}

The attribute of decoction - guru - slow acting and laghu - fast acting depends upon greater or lesser duration of heat respectively. 


\section{Procedure}

Fresh herbs are cut into small pieces and dry herbs are reduced to coarse powder. The ingredients are soaked in water overnight. The mixture is then boiled on slow flame with continuous stirring till the water gets reduced to the desired quantity.

The mixture is filtered with clean cloth to get the final product - decoction.

Figure - 1 Method of Preparation of Decoction

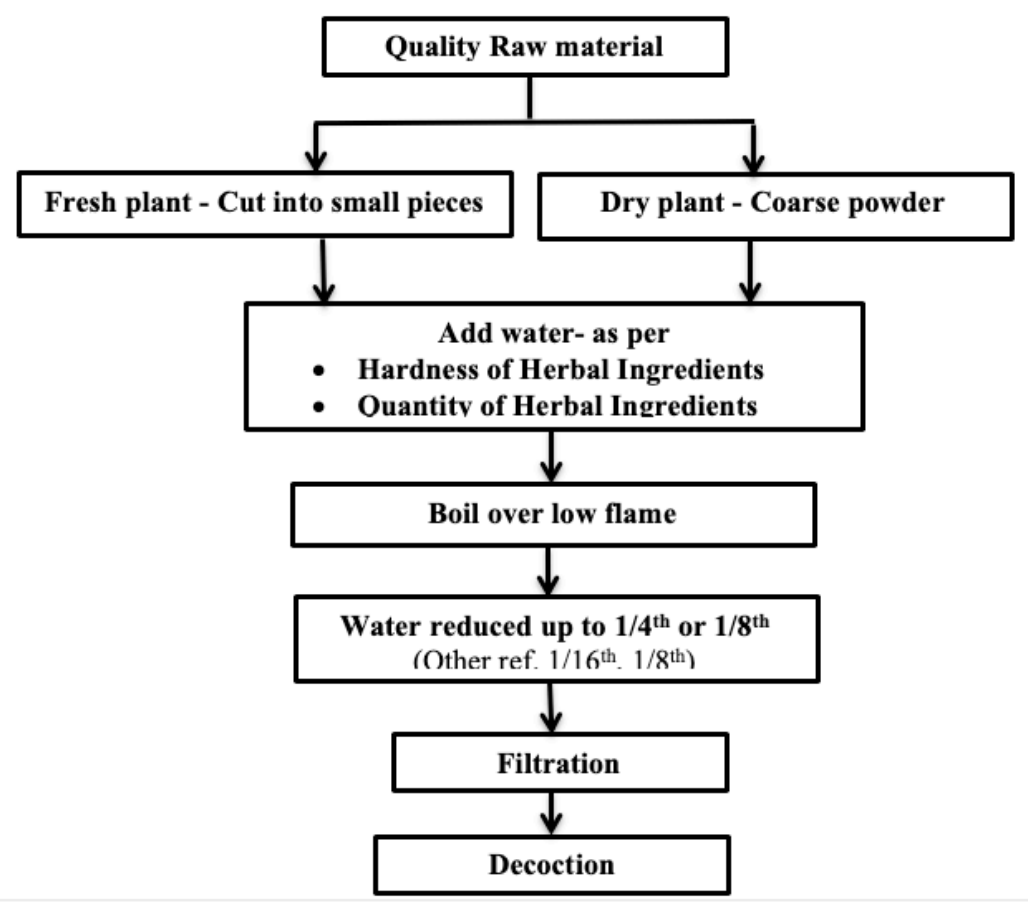

Therapeutic Classification of Kwatha, Decoctions

Harita has classified Kwathas as Saptavidha kashay kalpna (10) - 7 types as per the therapeutic activity. The desired maximum therapeutic effect is brought out with the administration of the decoction at specific time [Table 3].

Table 3: 7 Types of Kwatha as per Therapeutic Activity and Time of Administration

Sr. Kwatha type as per therapeutic

No. activity

1 Pachana - Digestive

2 Deepana - Appetizing

3 Shodhana-Purifying

4 Shamana - Alleviating doshas

5 Tarpan - Replenishing

6 Kledana - Lubricating

7 Shoshana-Absorbing

\section{Proportion of Time of administration} Reduction

1/2 Nisha; $2^{\text {nd }}$ yama - Night

$1 / 10^{\text {th }} \quad$ Aparhana-Afternoon

$1 / 12^{\text {th }} \quad$ Suryodyatpurve - Just before sunrise

$1 / 8^{\text {th }} \quad$ Poorvhane -Mid-morning

Equal Prabhate - Early morning

1/4th Prabhate - Early morning

$1 / 16^{\text {th }} \quad$ Nishithe;3rd yama - Night

administration for Ayurvedic treatments (37) [Table 4].

Table 4: Variation in Water Quantity and Reduction as per Therapeutic Use

\section{Therapeutic administration}

Aschotana - Eye drops

Asthapana / Niruha Basti-Medicated Enema

Gandush - Gargling

Mukhaprakshalana - Mouth Cleanser

Sneha - Oleaginous item

Seka - Fomentation

Vranaprakshalan / Vranashodha Wound Cleansing

Vamana - Emesis

Pana / Paneeya - Medicated Water

Ushnodaka - Warm Water

Yavagoo - Nutritional Gruel
Quantity and Reduction of water

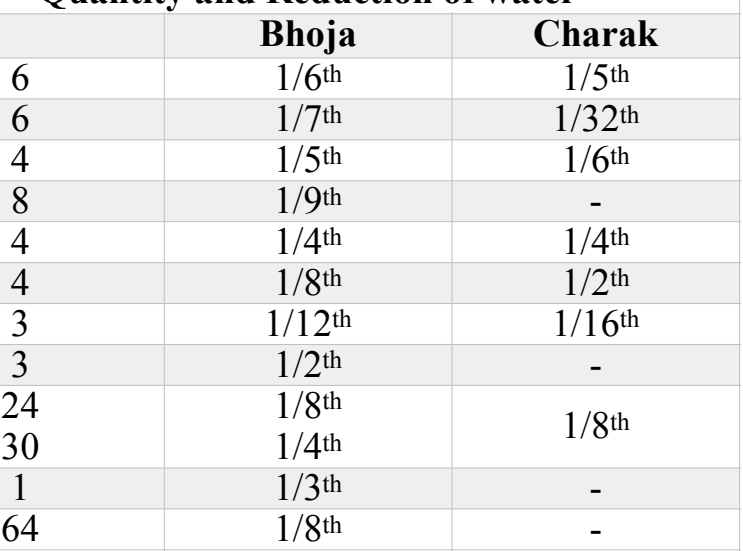




\section{Prakshepa Dravya - Additives}

Additives are added to increase palatability, therapeutic efficacy and stability of the final product. The quantity of additives varies as per the desired therapeutic effect (38) [Table 5].

Table 5: The Additives and Quantity Additives

Madhu- Honey

\begin{tabular}{|c|c|}
\hline Quantity & Disease \\
\hline $1 / 16^{\text {th }}$ of decoction & Vataja \\
\hline $1 / 8^{\text {th }}$ of kashaya & Pittaja \\
\hline $1 / 4^{\text {th }}$ of kashaya & Kaphaja \\
\hline $1 / 16^{\text {th }}$ of kashaya & Kaphaja \\
$1 / 8^{\text {th }}$ of kashaya & Pittaja \\
\hline $1 / 4^{\text {th }}$ of kashaya & Vataja \\
\hline
\end{tabular}

Ksheera- Milk, Ghrita-Gomutra- Cow's urine, Dravadravya-Liquid, KalkaPaste, Churna -Powder, Guggulu- Gum resin [Formulations prepared from resin of Commiphora mukul] Jiraka- Cuminum cyminum, Guggulu, Lavana-Salt, Shilajatu- Asphaltum, Hingu - Resin of Ferula narthex, Trikatu-3 pungents - Black pepper (Piper nigrum), Long pepper (Piper longum) and powder of Ginger (Zingiber officinale)]

\section{1 karsha- 10 gram}

\section{1 shana each- 3} gram each

\section{Quality Parameters - Siddhi lakshana (39)}

- The decoction should have the aroma, taste and color of the ingredients used.

- It should be free of any suspended particles.

- The residue after filtration should be tasteless.

- The expected or desirable quantity should be obtained as a final product.

\section{Poor-Quality of Decoction}

The decoction that becomes Krishna - black, neela - blue and raktavarna - red in color or picchila - sticky, dagdha - over-heated, kunapagandhi or visragandha - odor loses its efficacy and should not be used.(40)

\section{Finished Product}

The decoction that encompasses varna- color and gandha- smell of the ingredients, and does not have ghanatva- hardness or picchilata- stickiness is uttama- of optimum quality and amrutopama-effective.(39)

\section{Administration (41)}

The decoction is to be consumed lukewarm and only after proper digestion of aaharrasa-food. It should not be consumed after meals.

- Generally, and specially in Vata disorders it is prescribed to be consumed lukewarm and cold in Pitta disorders.

- The decoction is to be consumed in the morning unless otherwise specified.

- Decoction should not be reheated.

\section{Matra- Dosage}

The dosage of the decoction varies as per the age and disease condition. [Table 6]

Table 6: Dosage

\begin{tabular}{|l|l|}
\hline $\begin{array}{l}\text { Acharya Sharangadhara }(41) \\
\text { Vachaspatyam(42) }\end{array}$ & 2 palas $(96 \mathrm{ml})$ \\
\hline Uttamamatra-Ideal dose & 1 pala $(48 \mathrm{ml})$ \\
\hline Madhyamamatra-Medium dose & 3 Karsha $(36 \mathrm{ml})$ \\
\hline Avaramatra - Minimum dose & $1 / 2$ pala $(24 \mathrm{ml})$ \\
\hline Deeptanala mahakaya-For good digestive capacity & 1 Anjali $(120$ to $280 \mathrm{ml})$ \\
& $\begin{array}{l}\text { variable as per } \\
\text { individual need. }\end{array}$ \\
\hline Others & 1 Prasruti $(96 \mathrm{ml})$ \\
\hline
\end{tabular}

Shelf-life of decoction is one yama- 3 hours. 
The decoction is not intended for storage.

\section{Advantages and Disadvantages \\ Advantages}

- Decoction is prescribed for both internal as well as external ailments.

- It is absorbed quickly through the gut because of large surface area.

- It has a wide range of therapeutic uses.

- It is useful for different modes of administration, e.g. basti- medicated enema, nasya-nasal drops, nadisweda \& dharasweda-variety of hot foementation, dhavana- washing, prakshalana- cleansing and ashchotanaeyedrops.

- It is used as a base to prepare other formulations, e.g. ghrita -medicated ghee, taila medicated oil, arishtamedicated wine and others.

- It is used in other pharmaceutical processes e.g. as bhavana dravya- trituration, shodhana dravyadetoxification and anupana- vehicle with other dosage form.

\section{Disadvantages}

- It has a small shelf life; microbial contamination occurs if stored for a long time.

- It is required to be administered in large quantities for desirable therapeutic effect.

- It has poor patient compliance because of taste, especially if bitter.

- Decoction, as a liquid requires extra care while handling, packaging or transport.

- Addition of preservatives in the context of commercial preparations may lead to undesired effects such as irritation of mucous membrane.

- It is not useful for heat-sensitive ingredients.

- Volatile components may be lost during heating.

- Altered method of preparation on a large scale, if not done right, may lead to compromised efficacy and at times adverse effect if not stored right.

\section{Upakalpana of Kwath-allied formulations of decoction}

Though decoction forms a base of many Ayurvedic formulations the scarcity of crude herbs, the short life of decoction, the not so acceptable taste and dosage variations limit its use.

To overcome these problems, Upakalpanas- allied formulations are developed by using basic principles of Pancha vidha kashaya kalpana- five basic formulations. The development of Upakalpanas aims at enhancing the potency and selectivity in the pharmacological activity. The following allied formulations can be categorized with Kwatha kalpana. [Table 7]

Table 7: Allied formulations of Kwatha

\begin{tabular}{|c|c|c|c|}
\hline Formulation & Method of Preparation & Dosage & Indications \\
\hline $\begin{array}{l}\text { Pramathya (44) appetizer - } \\
\text { Ingredients are added in } \\
\text { form of paste] }\end{array}$ & $\begin{array}{l}\text { Medicated paste } 1 \text { part }+ \\
\text { water } 8 \text { parts }=\text { reduce to } \\
1 / 4^{\text {th }}\end{array}$ & 1-2 pala (48-96 gm) & $\begin{array}{l}\text { Digestive as pathya } \\
\text { (wholesome diet) }\end{array}$ \\
\hline $\begin{array}{l}\text { Paneeya (45)- Medicated } \\
\text { water }\end{array}$ & $\begin{array}{l}\text { Ingredients }-1 \text { part }+ \text { water } \\
-64 \text { parts }=\text { reduced to half }\end{array}$ & 2 pala (96 gm) & drinking and cooking \\
\hline $\begin{array}{l}\text { Ushnodaka (46) -Boiled } \\
\text { water } \\
\text { Sadangpaniya, Water with } \\
6 \text { ingredients }\end{array}$ & Lukewarm water & $\begin{array}{l}1 / 8^{\text {th }}, 1 / 4^{\text {th }}, 1 / 2^{\text {th }} \text { reduction } \\
\text { of water. }\end{array}$ & $\begin{array}{l}\text { Base for decoction and } \\
\text { such other formulations. } \\
\text { Indigestion, Fevers }\end{array}$ \\
\hline $\begin{array}{l}\text { Ksheera paka (47) - } \\
\text { Medicated milk }\end{array}$ & $\begin{array}{l}\text { 1] Herbs: Milk: Water } \\
(1: 8: 32) \\
\text { 2] Herbs: Milk: Water } \\
(1: 15: 15) \\
\text { Boiled till } \\
\text { ksheeravashesha the water } \\
\text { part gets reduced }\end{array}$ & $\begin{array}{l}\text { Specific to indication and } \\
\text { the patient }\end{array}$ & $\begin{array}{l}\text { Amashoola, Jeernajwar- } \\
\text { Chronic fever } \\
\text { Arjunkshirpaka- } \\
\text { Cardiovascular diseases } \\
\text { Rasonakshirpak- } \\
\text { Rheumatoid arthritis }\end{array}$ \\
\hline $\begin{array}{l}\text { Mamsa Rasa(48) Meat } \\
\text { soup }\end{array}$ & $\begin{array}{l}2,4,6 \text { and } 8 \text { parts of water } \\
\text { is added as per the nature } \\
\text { of chopped meat }\end{array}$ & --- & $\begin{array}{l}\text { Preenan- replenishment. } \\
\text { anorexia, cough, asthma }\end{array}$ \\
\hline
\end{tabular}

Modifications in kwatha kalpana $(49,50)$

The newer methods of preparations and modified forms have been developed for Kwatha Kalpana in the academic, commercial or industrial set up, and have some merits and demerits. [ Table - 8] 


\section{Table 8: Modifications in Kwatha Kalpana}

\begin{tabular}{|c|c|}
\hline Modification & Merits and Demerits \\
\hline Tablet, Ghanavati & $\begin{array}{l}\text { Unit dosage form, taste of kwatha can be masked, } \\
\text { easy administration, easy to carry, higher shelf life, patient compliant. }\end{array}$ \\
\hline Kashaya sookshmachurna & Can be stored for longer periods without losing its potency, less time-consuming. \\
\hline Arishta & $\begin{array}{l}\text { Increased shelf life, better palatability, self-generated alcohol acts as preservative, easy } \\
\text { to absorb, quick in action. } \\
\text { Demerits: takes more time for preparation. }\end{array}$ \\
\hline Syrup & $\begin{array}{l}\text { Better shelf life, palatable, small dosage. } \\
\text { Demerits: Change in taste, also may compromise therapeutic activity. }\end{array}$ \\
\hline Arka & $\begin{array}{l}\text { Easy preparation and administration, no need of preservatives. } \\
\text { lower dose, palatability, easy administration, longer shelf life. }\end{array}$ \\
\hline Granules & Increase in bulk density, uniform particle size, safe, effective. \\
\hline Dip bags / Sachets & $\begin{array}{l}\text { Easy to use and store. } \\
\text { Maintenance of the purity for instant preparation. }\end{array}$ \\
\hline
\end{tabular}

Failure in the preparation of kwatha - decoction

Product may get compromised as a consequence of not following the specific procedure. [Table 9]

Table 9: Failures in the Preparation of Kwatha- Decoction

Problems
Vessels-Size and shape
Shallow vessel - important constituents may get
evaporated.
Copper vessel, if not of good quality may react with
some of the ingredients and may become toxic.
Water - the change in quantity may compromise the
therapeutic efficacy.
Heat, Temperature Control -if not regulated may
decompose some of the important constituents.

Particle size of ingredients - the change in particle size compromises the efficacy of the final product.

\section{Industrial (Large scale) Production \\ Solid-Liquid Extraction Method (51)}

In the large-scale industrial preparation (bottled decoction), steam jacketed vessels or boilers are used. In this method, instead of directly boiling the drug and water, heat is transferred to the mixture indirectly through steam filled jackets.

The drugs employed are washed, dried and the size is reduced to about $1 / 8^{\text {th }}-1 / 4^{\text {th }}$ that of their former size, crushed and then fed to the drug boiler. A mechanical revolving chipping machine is used for size reduction of drugs. The size reduction helps to reduce the boiling time from 16-21 hours to 6 hours and in turn obtain the amount of maximum extraction solution equal to that of the conventional boiling method. This extraction method saves time and material and improves the quality of the product compared to the conventional method because it reduces the caramelization to a great extent and at the same time becomes cost effective.

\section{Prolongation of Shelf-life Use of Preservatives}

The shelf life of decoction is very small, and itis advised that it be used immediately after preparation. It cannot be preserved for a longer duration. Therefore, it becomes necessary to use the preservatives which are inert and could maintain drug potency for a longer period. Though there are many
Solutions
Long length and narrow mouth can help in preserving

all-important phyto-constituents.

Chemically inert vessels can be used.

Water should be taken as per the ratio mentioned.

Mild to moderate heat $\left[85-90^{\circ} \mathrm{C}\right]$ should be maintained throughout the process.

Coarse powder should be used.

such preservatives available, sodium benzoate is preferred for the industrial production.(52)

\section{Dehydration}

Nowadays the decoction prepared is produced in the form of dehydrated powder with spray drying technique. It is concentrated to $22-25 \%$ T.D.S. (Total Dissolved Solids) in the solid dehydrated form that improves its shelf life. In this process, water- the medium responsible for putrefactive spoilage is eliminated, thereby no preservative is deemed necessary.(53)

\section{Granules}

The decoctions used previously are not preferred now because of the time-consuming process. It has given rise to different easily usable forms as industrial products. These various preparations in liquid form either contain sugar or preservatives or are in fermented form to increase the shelf life leading to variance in efficacy. Mostly, a mismatch is observed in the dose, as suggested of the fresh decoction and these liquids. Inappropriate dose consumption may also compromise the effectiveness. There are also issues of transportation because of the chances of leakage, breakage or spillage. Efforts are being made to overcome these issues. The liquid form has been converted to readily soluble granules (54) maintaining the same efficacy as freshly prepared decoction with the 
help of modern technology. These are available in a single dose pouch of 2 gms each. The ingredients are granulized, micronized and standardized to develop consistency and maintain the efficacy. The granulated form is easy to use with advantages of elimination of leakage or breakage.

\section{Discussion}

\section{Size of Drug}

Acharya Charaka has clearly indicated that raw drug should be cut into pieces for the preparation of decoction.(19) It must be emphasized that the very high degree of size reduction is not preferred because an extensive size reduction is likely to lead to decomposition of the constituents or loss of volatile material. The degree of size reduction will also depend on the botanical structure of the drug. Yavakuta- coarse powder size is ideal for preparation of the decoction. Presently it is observed that $60-100$ mesh size crude herbs are used for preparing a decoction.

\section{Importance of Soaking}

Soaking enables the dried drug to become porous, thus allowing the solvent to penetrate the cells. This process is dependent on the character of the drug. The cell walls consist of cellulose molecules known as micelle. In the fresh material, they are surrounded by a film of water. After drying, the film is lost, and the micelles move together to form a continuous membrane. When the dry ingredients are moistened, the process is reversed, and the micelles takes up a liquid film and tissues swell up. The amount of swelling is variable. Swelling is observed more with liquids, those having hydroxyl groups form a great part of the molecule which is why water causes considerable swelling. Hence, it is advisable to soak coarse powder of the ingredients in the water for some time.

\section{Quantity of Water}

It has been observed that the ratio of drug and water in decoction varies in different classics according to the consistency and quantity of the drug. The quantity of water and its reduction to prepare the final decoction depends upon its therapeutic use which may be internal, external or for the preparation of other dosage forms.

\section{Quantum of Heat}

Mrudu- mild heat (around $100^{\circ} \mathrm{C}$ ) is applied to avoid dagdha and picchila-over burnt and sticky and to obtain Samyakviryautkrishtata (41) highly potent preparation. Scientifically, most of the alkaloids and other substances get deteriorated at high temperature.

\section{Effect of Agitation}

The rate of transfer of solute from the boundary layer to the surrounding depends on the concentration gradient between these two regions and on the thickness of the diffusion pathway. Agitation helps to increase a dissolution pathway. Also, bringing fresh solvent in contact with the boundary layer produces high value for the concentration gradient. It is envisaged that the rate of dissolution may markedly be affected by agitation or stirring.

\section{Therapeutic Indications}

Use of kwatha has been in practice since the Vedic period, which goes back to 1500 BCE. Since then $k$ watha or decoction, as it is better known today, has continued to hold its position as an important ayurvedic formulation which also continues to interest the modern pharmaceutical scientists. Part of the recognizable progress in the use of kwatha is its preparation as a polyherbal formulation. Polyherbal formulations have also been used since a long period of time in Ayurveda for the treatment of various disorders.

Kwatha Manimala describes about 394 Kwatha formulations used in various disease conditions. Ayurved Formulary of India mentions 25 Kwatha churna, which are useful in various disorders such as Fever, Retention of Urine, Diarrhea, Inflammation, Various types of gynecological disorders, Arthritis, Rheumatoid arthritis. $(55,56,57)$

One such example is Tila kwatha, which is a polyherbal formulation. Tila kwatha has been prescribed for various menstrual conditions like nastapushpataamenorrhea, raktagulma- composite enlargement due to vitiated blood (58). One more example of polyherbal kwatha formulation is Vasaguduchyadi kwatha. This is used for the treatment of kamala - jaundice, panduroga - anemia and such other liver diseases. The conventional allopathic medicines for liver diseases, in specific, fail to provide satisfactory elimination of the ailment. Synthetic drugs used for the treatment of such severe liver disorders show equally severe side effects because of which their use is limited (59). This is the reason why such polyherbal kwatha formulations not only persist but are also preferred by physicians.

\section{Conclusions}

Kwatha (decoction) is the potent therapeutic preparation in liquid form containing water soluble constituents responsible for therapeutic activity. Despite having high therapeutic efficacy, the use becomes formidable due to the cumbersome process, poor palatability and reduced stability. Efforts are being made to overcome these issues with the use of modern techniques like spray drying and development of dosage forms that could be used easily without compromising the efficacy. A comprehensive pharmaceutical research in this area is desirable.

\section{Acknowledgement}

We acknowledge the textual and technical support provided by Dr. Vandana Kozarekar.

\section{References}

1. Shashtri Kashinath, Chaturvedi Gorakhnath, Charak Samhita of Acharya Charak, Vidyotini Hindi commentary, Sutra Sthan 04/07. 12th edition. Varanasi; Chaukhambha Bharati Academy; $1984.68 \mathrm{p}$ 
2. Bhatt N, Deshpande M, Valvi A. A Critical Review of Standardization of Ayurvedic Asava - Arishta Part I - Review and Status. World Journal of Pharmaceutical Research. 2016; 5(5); 1523-1542p.

3. Sharma Pandit Shriram, Atharvaveda part 1, Kand 4, Shukta 7/3, 1st edition, Mathura; Yug Nirman Yojana; reprint $2005.114 \mathrm{p}$

4. Manmatha Nath Dutt, The Garud Puran: Dhanvantari Samhita, Chapter CXCVIII - Various medicinal compounds disclosed by Hari to Hara, $1908 \mathrm{p}$, assessed from http://www.wisdomlib.org/ hinduism/book/the-garuda-purana, 29 May 2020. $7.30 \mathrm{pm}$

5. Paradkar Vaidya Harishashtri, Ashtanga Hridaya of Acharya Vagbhatt, Kalpa Sthana 6:10. 7th edition, Varanasi; Chaukhambha Orientalia, re print 1982. $772 \mathrm{p}$

6. Acharya Yadavaji T., Charak Samhita of Acharya Charaka, Chakrapani, Ayurved Deepika Commentary. 1st edition. Chikitsa Sthan 3:199. Varanasi; Chaukhambha Surbharati; re print 1992. $415 \mathrm{p}$

7. Shashtri Ambikadatta, Sushrut Samhita of Acharya Shshruta, 14th edition, Sutrasthana 44:91. Varanasi; Chaukhamba Sanskrit Sansthan; 2003. 167p

8. Murthy K.R. Srikanta, Sharangadhar Samhita of Acharya Sharangadhar, Madhyamkhanda 2:166-170. 1st edition. Varanasi: Chaukhambha Orientalia; 1984. 76p

9. Khemraj Shri Krushnadas, Bhavaprakash of Bhavmishra Purvakhanda, Dwitiya bhag, (second part). Mumbai; Shri Vanketshevar Publisher, 1906. 395-396p [http:epustalaya.com/books/ 6343, bhavprakash-part 2 by Khemaraj- shrikrushnadas]

10. Hemaraj Sharma, Kashyapa Samhita of Vruddha Jivaka, Khila Sthana 3:35. 4th edition. Varanasi; Chaukhambha sanskrit series; 1994. 243p

11. Pandey Jaimini, Harit Samhita of Harit. 1:47. 1st edition. Varanasi; Chaukhambha Vishvabharati; 2010. 186-187p.

12. Prasad P. V. N. R, Illustrated Bhaishajya kalpana. 2nd edition. Varanasi; Chaukhambha Krishnasdas Academy; 2008. 145p

13. Prasad P. V. N. R, Illustrated Bhaishajya kalpana. 2nd edition. Varanasi; Chaukhambha Krishnasdas Academy; 2008. 143p

14. Deva Raja Radhakanta, Shabdakalpadrum Vol.2. Varanasi; Chaukhambha Sanskrit series; 1961. 937 $\mathrm{p}$

15. Gupta Kaviraja Umeshachandra, Vaidyaka Shabda Sindhu [A comprehensive lexicon of Hindu medical terms and name of drugs]. Kolkatta; Girish Vaidyaratna Press; $1894.219 \mathrm{p}$

16. Tarkavachaspati Taranath, Vachaspatyam (a comprehensive Sanskrit dictionary). 1st edition Varanasi; Chaukhambha surbharati; 1970. vol.3; $1838 \mathrm{p}$

17. Venimadhavshashtri Joshi, Ayurvediya Shabdakosha. 1st edition. Mumbai; Maharashtra Rajya Sahitya, A. D. Mandal; 1968. 330p
18. Paradakar Vaidya Harishashtri, Ashtanga Hridaya of Acharya Vagbhatt, Kalpa Sthana 6:13. 7th edition, Varanasi; Chaukhambha Orientalia; re print $1982.773 \mathrm{p}$

19. Shashtri Kashinath, Chaturvedi Gorakhnath, Charaksamhita of Acharya Charak, vidyotini Hindi commentary, Vimana Sthana 07:17. 12th Edition, Varanasi; Chaukhamba Bharati Academy; 1984. $729 \mathrm{p}$

20. Shashtri Ambikadatta, Sushrut Samhita of Acharya Shshruta. Chikitsa Sthana 31:6. 14th edition. Varanasi; Chaukhambha Sanskrit Sansthan; 2003. $133-134 p$

21. Shashtri Ambikadatta, Sushrut Samhita of Acharya Shshruta, Sutrasthana 44:81. 14th edition, Varanasi; Chaukhambha Sanskrit Sansthan; 2003. 166p

22. Vaidya Lalchandrashashtri, Ashtang Sangrah of Vagbhatt with hindi translation, Kalpasthan 8:33. 1st edition. Nagpur; Shri Baidyanath Ayurved Bhavan Pvt. Ltd; 1989.1146p

23. Murthy K.R. Srikanta, Sharangadhar Samhita of Acharya Sharangadhar, Madhyamkhanda 2:1-2. 1st edition. Varanasi; Chaukhambha Orientalia; 1984. $56 \mathrm{p}$

24. Murthy K.R. Srikanta, Sharangadhar Samhita of Acharya Sharangadhar, Madhyamkhanda 2:7. 1st edition. Varanasi; Chaukhambha Orientalia; 1984. $57 \mathrm{p}$

25. Hemaraj Sharma, Kashyapa Samhita of Vruddha Jivaka, Khila Sthana 3:4.2 4th edition. Varanasi; Chaukhambha sanskrit series; 1994. 243-244p

26. Acharya Yadavaji Trikumji, Dravyagun Vigyanam Uttarardha, Pratham Paribhasha Khanda. 2nd edition. Mumbai; Nirnaysagar Press; 1996. 180p

27. LaxmipatiShashtri, Yogaratnakar with vidyotini commentary edited by Shashtri Brahmashankar. $4^{\text {th }}$ edition. Varanasi; Chaukhambha Sanskrit sansthan; 1988.120p

28. Vaidya Lalchandrashashtri, Ashtang Sangrah of Vagbhatt, Kalpasthan 8:34. 1st edition. Nagpur; Shri Baidyanath Ayurved Bhavan Pvt. Ltd. 1989;1146p

29. Sharma P.V. Sushrut Samhita of Acharya Shshruta, Chikitsa Sthana 31:8. 14th edition. Varanasi; Chaukhambha Sanskrit Sansthan; 2003. 134p

30. Vaidya Lalchandrashashtri, Ashtang Sangrah of Vagbhatt, Kalpasthan 8:33. 1st edition. Nagpur; Shri Baidyanath Ayurved Bhavan Pvt. Ltd; 1989. $1146 \mathrm{p}$

31. Reddy Sekhar P. Bhaishjya Kalpana Vijnanam. 1st edition. Varanasi; Chaukhambha Sanskrit Sansthan; 2013, Chapter 7; 113p

32. Vaidya Bhagvan Das, Latitesh Kashyap. Itro Chemistry of Ayurved Rasashastra [Based on Ayurved saukhayam of Todaranand series 9]. New Delhi; concept publishing company; 2002. 146 $147 \mathrm{p}$

33. Murthy K.R. Srikanta, Sharangadhar Samhita of Acharya Sharangadhar, Madhyamkhanda 9;3.1st edition. Varanasi; Chaukhambha Orientalia; 1984. $116 \mathrm{p}$ 
34. Vyas M, Yadav P, Shukla VJ, Patgiri BJ, Prajapati PK. Pharmaceutical Evaluation of Brihatpanchamoola Kwatha Prepared by Root Bark And Stem Bark. International Journal of Pharmaceutical \& Biological Archives, 2010; 1(5): 436-441p.

35. Patil S, Chaudhary AK. Quantitative Estimation of Guduchi Ghana obtained from different amount of water used for Kwatha. International Journal of Pharmaceutical Archive. 2013; 2(6); 160-164p.

36. Honwad Sudheendra. A Handbook of Standardization of Ayurvedic formulations chapter 4. First Edition. Varanasi; Chaukhambha Orientalia; 2012.93p.

37. Prasad P. V. N. R, Illustrated Bhaishjya kalpana. 2nd edition. Varanasi; Chaukhambha Krishnasdas Academy; 2008. 145p

38. Murthy K.R. Srikanta, Sharangadhar Samhita of Acharya Sharangadhar, Madhyamkhanda 2:4-6.1st edition. Varanasi; Chaukhambha Orientalia; 1984. $56-57 \mathrm{p}$

39. Tripathi Hariprasad, Harit Samhita of Acharya Harit, 1st edition, Varanasi; Chaukhambha Sanskrit series; 2005. 524p.

40. Tripathi Hariprasad, Harit Samhita of Acharya Harit, 1st edition, Varanasi; Chaukhambha Sanskrit series; 2005. 106-107p.

41. Murthy K.R. Srikanta, Sharangadhar Samhita of Acharya Sharangadhar, Madhyamkhanda 2:3. 1st edition. Varanasi; Chaukhambha Orientalia; 1984. $56 \mathrm{p}$

42. Tarkavachaspati Taranath, Vachaspatyam - a comprehensive Sanskrit dictionary. $1^{\text {st }}$ edition. Varanasi; Chaukhambha Sanskrit series; 1970. Vol $3,1595 \mathrm{p}, 2482 \mathrm{p}$

43. Deva Raja Radhakanta, Shabdakalpadrum. Varanasi; Chaukhambha Sanskrit series; 1961. Vol.2, 937p

44. Murthy K.R. Srikanta, Sharangadhar Samhita of Acharya Sharangadhar, Madhyamkhanda 2:150. 1st edition. Varanasi; Chaukhambha Orientalia; 1984. $73 p$

45. Murthy K.R. Srikanta, Sharangadhar Samhita of Acharya Sharangadhar, Madhyamkhanda 2:157. 1st edition. Varanasi; Chaukhambha Orientalia; 1984. $74 \mathrm{p}$

46. Murthy K.R. Srikanta, Sharangadhar Samhita of Acharya Sharangadhar, Madhyamkhanda 2:159-160. 1st edition. Varanasi; Chaukhambha Orientalia; $1984.75 \mathrm{p}$

47. Murthy K.R. Srikanta, Sharangadhar Samhita of Acharya Sharangadhar, Madhyamkhanda 2:161. 1st edition. Varanasi; Chaukhambha Orientalia; 1984. $75 \mathrm{p}$
48. Murthy K.R. Srikantha, Bhavaprakash of Acharya Bhavmishra, Krutanna Varga; 102- 106. 1st edition. Varanasi; Krisanadas Academy; 1998. 430p

49. Deepthi CP, Ganti Basavaraj Y, Sreekanth G, Rohit KS, Anu PK, Modifications of Pancha Vidha Kashaya Kalpana; Unique Journal of Ayurvedic and Herbal Medicines. 2015; 03(05); 60-63 p

50. Neetu, Singhal HK, Mitra S. and Sharma K, A Comparative pharmaceutico-chemical study of Gojivadikwath and its granules w.s.r to stability profile, Ayurpharm International Journal of Ayurveda and Allied Science. 2013; 2(04); 105-113p.

51. Handa SS, Khanuja SPS, Longo G, Rakesh DD, Extraction technologies for medicinal and aromatic plants; International Centre For Science and High Technology Trieste. Italy; 2008; 93p.

52. Kar Amaresh, Mallika KJ, Harini A. Journal of Pharmacognosy and Phytochemistry 2018; 7(4): 3056-3060 (sodium Benzoete)

53. Singh Varun Kumar, Reddy K. R. C. Pharmaceutical processing and standardization of modified dosage form of Lodhradi Kashaya as spray dried powder. International Journal of Green Pharmacy. Oct-Dec 2015; 9(4): 252

54. Pandya H, Sharma and Prajapati PK, Standardization and quality control parameter of Dashmoola kwatha granules for instant use: An Ayurvedic formulation, American International Journal of Contemporary Scientific Research. 2014; 1(4); 10-16p.

55. Singh M. K. Kwatha Manimala Translated in Hindi. 1st edition. Varanasi: Chaukhambha Sanskrit Sansthan; 1970.

56. Government of India, Ministry of Health and Family Welfare, Dept. of Indian systems of Medicine \& Homoeopathy, The Ayurvedic Formulary of India. Part I, Part A: Kwatha Churna. New Delhi, 2000; 165p

57. Meena V, Bhushan S and Chaudhary AK: Kwatha Kalpana: It's Versatility with Probable Advancement, Asian Journal of Pharmaceutics. Oct-Dec 2017(Suppl); 11 (4); S678-S683p.

58. Vasudevan A, Dei L, Harisha C R and Shukla V J: Pharmacognostical and Phyto-Chemical Standardization of Tilakwatha: A Polyherbal Formulation. International Journal of Pharmaceutical \& Biological Archives. 2012; 3(6);1410-1414p

59. Kotecha Kalpu, Harisha CR, Shukla VJ, Prajapati PK, Ravishankar B. Pharmacognostical and phytochemical standardization of Vasagduchyadi kwatha a poly herbal Ayurvedic formulation. Pharma Science Monitor - An International Journal of Pharmaceutical Sciences. July 2012; 3(3); 2291-2303p. 